\title{
Effect of high-pressure treatment on denaturation of bovine lactoferrin and lactoperoxidase
}

\author{
C. Mazri, ${ }^{\star}$ L. Sánchez, ${ }^{\star}$ S. J. Ramos, $†$ M. Calvo, ${ }^{\star}$ and M. D. Pérez ${ }^{\star 1}$ \\ *Tecnología de los Alimentos, Facultad de Veterinaria, Universidad de Zaragoza, 50013-Zaragoza, Spain \\ †Centro Nacional de Tecnología y Seguridad Alimentaria, 31570-San Adrián, Navarra, Spain
}

\begin{abstract}
Lactoferrin and lactoperoxidase are whey proteins with biological properties that may provide health benefits to consumers. These properties are vulnerable to potentially denaturing conditions during processing. High-pressure treatment is an appealing alternative to the traditional heat processing of foods because it exerts an antimicrobial effect without changing the sensory and nutritional quality of foods. In this work, the effect of high-pressure treatment on the denaturation of lactoferrin and lactoperoxidase present in skim milk and whey, and as isolated proteins in buffer, was studied over a pressure range of 450 to $700 \mathrm{MPa}$ at $20^{\circ} \mathrm{C}$. Denaturation of lactoferrin was measured by the loss of reactivity with their specific antibodies using a sandwich ELISA. Denaturation of lactoperoxidase was determined by measuring the loss of enzymatic activity using a spectrophotometric technique. No substantial inactivation of lactoperoxidase was observed in any treatment assayed. The concentration of the residual immunoreactive lactoferrin after each pressure treatment was determined, and the data were subjected to kinetic analysis to obtain $\mathrm{D}$ and $\mathrm{Z}$ values. Denaturation of lactoferrin increased with pressure and holding time, and D values were lower when lactoferrin was treated in whey than in milk, and lower in both whey and milk than in phosphate buffer. Thus, protein is denatured more slowly in buffer and in milk than in whey. Denaturation of lactoferrin in the 3 media was found to follow a reaction order of $n=1.5$. Volumes of activation of about $-34.77,-24.35$, and $-24.09 \mathrm{~mL} /$ mol were obtained for lactoferrin treated in skim milk, whey, and buffer, respectively, indicating a decrease in protein volume under pressure.
\end{abstract}

Key words: lactoferrin, lactoperoxidase, high pressure, denaturation kinetics

Received June 29, 2011.

Accepted October 23, 2011.

${ }^{1}$ Corresponding author: dperez@unizar.es

\section{INTRODUCTION}

Bovine milk contains several bioactive components that exert a protective effect against infectious agents. Lactoferrin, lactoperoxidase, and lysozyme are nonspecific factors that are known to be effective against microorganisms (Severin and Wenshui, 2005). Lactoferrin is a basic glycoprotein present in milk that belongs to a family of iron-binding proteins (Ward et al., 2005); it consists of a single polypeptide chain with a molecular weight of $80 \mathrm{kDa}$. Crystallographic analysis has revealed that lactoferrin is structured in 2 globular lobes, each lobe containing one iron-binding site in an interdomain cleft (Wakabayashi et al., 2006).

Lactoferrin exhibits both bacteriostatic and bactericidal activity against a wide range of microorganisms, including gram-positive and gram-negative bacteria. The main antimicrobial mechanism of lactoferrin is attributed to its capacity to sequester iron, thereby depriving potential pathogens of this essential nutrient. Lactoferrin also can bind to the lipopolysaccharide of gram-negative bacteria, which causes destabilization of the bacterial cell wall (Farnaud and Evans, 2005). Other biological activities have been attributed to lactoferrin, such as regulation of iron absorption, immune system modulation, cellular growth promoting activity, and antitumor activity (Ward et al., 2005). Recently, oral administration of lactoferrin has been reported to benefit human health because of its biological functions (Wakabayashi et al., 2006). These findings support the use of lactoferrin as an ingredient in foods and special products (Shah, 2001). Until now, bovine lactoferrin obtained on a large scale from bovine skim milk and whey has been used as a supplement in products such as infant formula, yogurt, specialized milk-based and other beverages, and nutritional supplements as well as in cosmetics and products for dental hygiene (Wakabayashi et al., 2006; Tomita et al., 2009).

Lactoperoxidase is a basic protein present in milk that consists of a single polypeptide chain with a molecular weight of approximately $78 \mathrm{kDa}$ (Seifu et al., 2005). It plays an important role in protecting the lactating mammary gland and the intestinal tract of the new- 
born against pathogenic microorganisms (Naidu, 2000). Lactoperoxidase needs the presence of 2 other factors, hydrogen peroxide and thiocyanate, in equal amounts to develop its antimicrobial function. Lactoperoxidase catalyzes the peroxidation of thiocyanate, generating hypothiocyanite and other products that impair the function of bacterial metabolic enzymes (Pruitt and Kamau, 1991). The molecular mechanisms of such inhibitory effects have been identified from oxidative killing to blockage of glycolytic pathways or interference in cytopathic effects (Naidu, 2000).

The most widely recommended industrial application of the lactoperoxidase system in food production is in the dairy industry for the preservation of raw milk in tropical climates where refrigeration facilities are not available. However, other novel applications are being explored. Activation of the lactoperoxidase system has been reported to suppress excessive acid production of yoghurt during refrigerated storage; thus, it maintains a favorable balance between sweetness and sourness for at least 2 wk (Nakada et al, 1996).

Milk preserved by the lactoperoxidase system can be used to improve the microbiological quality of raw milk cheese (Seifu et al., 2005). Lactoperoxidase may also be used to preserve highly heat-sensitive foods such as salad dressings, spreads, beverages, dips, and desserts (Pruitt and Kamau, 1991). In addition, the lactoperoxidase system has been applied in the preservation of cosmetics, ophthalmic fluids, and products related to dental hygiene (Naidu, 2000; Seifu et al., 2005).

The stability of lactoferrin and lactoperoxidase to technological treatments commonly applied to foods is an important aspect to be considered when these proteins are intended for use as bioactive components in food. Thermal treatment of foods is extensively used to inactivate pathogenic and spoilage microorganisms and enzymes, to make them safe for human consumption, and to extend shelf-life. However, thermal treatments can result in some unfavorable changes, such as protein denaturation, nonenzymatic browning, and loss of vitamins and volatile compounds (Singh, 2004). The thermal stability of lactoferrin and lactoperoxidase has been well reported, these proteins being considered sensitive to heat treatment (Sánchez et al., 1992; Ludikhuyze et al., 2001; Marín et al., 2003).

Over the last decade, high-pressure treatment of foods and food components has gained interest as a nonthermal processing technology for preservation. The major benefit of applying high-pressure treatments in food processing is that it is effective in inactivating microorganisms and certain enzymes while leaving small molecules, such as flavor compounds and vitamins, intact (Rastogi et al., 2007). However, the sensitivity of proteins to high-pressure treatments varies along with changes in the molecular structures (Huppertz et al., 2002; López-Fandiño, 2006).

Some studies have been conducted on pressure-induced denaturation of lactoperoxidase, and discrepancies in results have been reported, likely because of the use of different media to treat the protein and different methods to measure denaturation. García-Graells et al. (2003) suggested the potential of the lactoperoxidase system to improve the bactericidal efficiency of highpressure treatment for food preservation. They found that the supplementation of bovine skim milk to the lactoperoxidase system strongly increased high-pressure inactivation of different bacteria.

To our knowledge, no reports on the effect of pressure treatment on denaturation of lactoferrin are available. Using electrophoresis, it has been shown that after treatment of whey protein concentrate solutions at 800 $\mathrm{MPa}$ for $30 \mathrm{~min}$, lactoferrin is found in disulfide-bonded aggregates formed with other whey proteins and that only a faint band of monomeric lactoferrin is present in the treated sample (Patel et al., 2004). Furthermore, high-pressure treatment of bacterial suspensions in the presence of lactoferrin has been reported to increase the bactericidal activity and spectrum of this protein against several vegetative bacteria (Masschalck et al., 2001). These findings have commercial significance regarding the use of high-pressure processing in the manufacture of safe and high-quality products containing lactoferrin or lactoperoxidase.

The aim of this work was to study the effect of highpressure treatment on denaturation of the minor whey proteins lactoferrin and lactoperoxidase. The present work includes the treatment of proteins present in skim milk and whey and as isolated proteins in buffer. We calculated kinetic parameters for the denaturation process of lactoferrin in the 3 media. The model allows the pressure-induced denaturation of lactoferrin to be calculated on the basis of pressure and holding time.

\section{MATERIALS AND METHODS}

\section{Materials}

Bovine lactoferrin, with an iron saturation of around $26 \%$, and lactoperoxidase were kindly donated by Fina Research (Seneffe, Belgium) and fresh raw bovine milk by Quesos Villa Corona (El Burgo de Ebro, Zaragoza, Spain). Tetramethylbenzidine substrate (TMB) was supplied by Zeu-Inmunotec (Zaragoza, Spain). Complete and incomplete Freund's adjuvant, ovalbumin, lactoperoxidase substrate 2,2'-azinobis (3-ethylbenzthiazoline-sulfonic acid; ABTS) and horseradish peroxidase (HRP; 250 to 503 units/mg) were supplied by Sigma (Poole, UK), and BrCN-activated Sepharose 4B 
was from Pharmacia Biotech (Uppsala, Sweden). The rest of the reagents and chemicals not otherwise specified were of analytical grade.

\section{Milk and Whey Preparation}

Milk was skimmed by centrifugation at $2,000 \times g$ at $4^{\circ} \mathrm{C}$ for $30 \mathrm{~min}$, followed by filtration of the subnatant through glass wool to remove fat particles. Fat concentration in skim milk, as determined by the Gerber method, was found to be less than $0.18 \%$ (wt/wt). Chy$\operatorname{mosin}(1 \mathrm{mg} / \mathrm{mL})$ was added to skim milk at $30 \mu \mathrm{L} / \mathrm{mL}$ and the milk was left to coagulate at $35^{\circ} \mathrm{C}$ for $45 \mathrm{~min}$. Finally, whey was centrifuged at $1,000 \times g$ for $15 \mathrm{~min}$ at $4^{\circ} \mathrm{C}$ to remove curd particles.

\section{Pressure Treatment}

Lactoferrin and lactoperoxidase were dissolved in 0.15 $M \mathrm{NaCl}, 10 \mathrm{~m} M$ potassium phosphate buffer ( $\mathrm{pH} 7.4$ ) at $200 \mu \mathrm{g} / \mathrm{mL}$. Samples of skim milk, whey, and protein solutions were introduced into Eppendorf tubes without headspace and treated in a Stansted Fluid Power FPG 11500B high-pressure food processor (Harlow, Essex, UK). The temperature of the samples, the chamber, and the pressurization fluid were pre-equilibrated to $20^{\circ} \mathrm{C}$ for at least $1 \mathrm{~h}$ before treatment. Temperature and pressure in the chamber were monitored throughout the run using data logging equipment. Rate of pressure increase was maintained at $240 \mathrm{MPa} / \mathrm{min}$. The increase and decrease of temperature during pressurization or depressurization was about $2^{\circ} \mathrm{C}$ per $100 \mathrm{MPa}$ as a result of adiabatic heating or cooling. Samples were treated from 450 to $700 \mathrm{MPa}$ for different times at $20^{\circ} \mathrm{C}$. After pressure treatment, the samples were stored at $4^{\circ} \mathrm{C}$ overnight before analysis.

\section{Isolation and Conjugation of Anti-Lactoferrin Antibodies}

Antisera against purified bovine lactoferrin were obtained in rabbits according to Wehbi et al. (2005). Specific anti-lactoferrin antibodies were obtained by immunoadsorption using a column with bovine lactoferrin insolubilized in Sepharose-4B. A volume of $15 \mathrm{~mL}$ of anti-lactoferrin antisera was applied to the column and washed with $150 \mathrm{~m} M \mathrm{NaCl}, 15 \mathrm{~m} M$ potassium phosphate buffer ( $\mathrm{pH}$ 7.4) until the absorbance of the eluate at $280 \mathrm{~nm}$ was $<0.02$. Retained antibodies were eluted with $0.5 \mathrm{M} \mathrm{NaCl}, 0.1 \mathrm{M}$ HCl-glycine buffer $(\mathrm{pH} 2.8)$ and immediately neutralized with $0.5 \mathrm{M}$ Tris buffer $(\mathrm{pH} 8.0)$. Finally, antibodies were dialyzed against potassium phosphate buffer at $4^{\circ} \mathrm{C}$ overnight, concentrated, and frozen at $-20^{\circ} \mathrm{C}$ until use. Purified anti-lactoferrin antibodies were conjugated with HRP using the periodate technique as described by Catty and Raykundalia (1989).

\section{Measurement of Lactoferrin Concentration}

A sandwich ELISA assay was developed to determine bovine lactoferrin following the method of Franco et al. (2010). Maxisorp microtritation plates (Nunc, Roskilde, Denmark) were coated with $100 \mu \mathrm{L}$ per well of antilactoferrin antibodies $(5 \mu \mathrm{g} / \mathrm{mL})$ in $15 \mathrm{mM} \mathrm{Na}_{2} \mathrm{CO}_{3}, 35$ $\mathrm{mM} \mathrm{HNaCO}$ buffer ( $\mathrm{pH} 9.6$ ), and incubated overnight at $4^{\circ} \mathrm{C}$. After washing the plates 3 times with $300 \mu \mathrm{L}$ per well of PBS $\left(8 \mathrm{~m} M \mathrm{Na}_{2} \mathrm{HPO}_{4}, 3 \mathrm{~m} M \mathrm{KCl}, 0.14\right.$

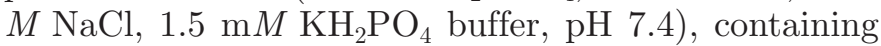
$0.05 \%$ Tween 20, blocking of residual protein binding sites was performed with $300 \mu \mathrm{L}$ of $3 \%$ (wt/vol) ovalbumin in PBS, at $37^{\circ} \mathrm{C}$ for $2 \mathrm{~h}$. The wells were washed again, and samples and lactoferrin standards from 10 to $1,000 \mathrm{ng} / \mathrm{mL}$ were added to wells and incubated for $1 \mathrm{~h}$. The plate was then washed 5 times and incubated with $100 \mu \mathrm{L}$ of HRP-labeled anti-lactoferrin antibodies in PBS for $1 \mathrm{~h}$ at $37^{\circ} \mathrm{C}$. Then, the plates were washed 5 times with PBS-Tween and incubated with $100 \mu \mathrm{L}$ of TMB substrate per well for $30 \mathrm{~min}$ at $37^{\circ} \mathrm{C}$. Finally, the enzymatic reaction was stopped by adding $50 \mu \mathrm{L}$ of $2 \mathrm{M} \mathrm{H}_{2} \mathrm{SO}_{4}$ per well, and the absorbance determined at $450 \mathrm{~nm}$ using a microplate reader (Labsystem Multiskan, Helsinki, Finland).

\section{Measurement of Enzymatic Activity of Lactoperoxidase}

Enzymatic activity was measured following the spectrophotometric method described previously (Marín et al., 2003). To each cuvette were added $50 \mu \mathrm{L}$ of sample and $1 \mathrm{~mL}$ of $0.65 \mathrm{mM}$ ABTS substrate in $0.1 \mathrm{M}$ sodium phosphate buffer ( $\mathrm{pH}$ 6.0). The reaction was initiated by adding $1 \mathrm{~mL}$ of $0.1 \mathrm{~m} M$ hydrogen peroxide. Increasing absorbance at $412 \mathrm{~nm}$ was measured during $1 \mathrm{~min}$ at $20^{\circ} \mathrm{C}$ in a UV-visible spectrophotometer (Unicam, Cambridge, UK) using a rate method. The blank was prepared with $1 \mathrm{~mL}$ of substrate, $50 \mu \mathrm{L}$ of sample, and $1 \mathrm{~mL}$ of phosphate buffer. The activity of lactoperoxidase was calculated from the slope of the linear part of the regression line when absorbance increase was plotted versus reaction time.

\section{Calculation of $D$ and $Z$ Values}

The time required for $90 \%$ protein denaturation at constant pressure (D value) was calculated for each treatment by regression analysis of the lines obtained by plotting the logarithm of immunoreactive lactofer- 
rin expressed as the percentage of the initial protein concentration against time. The $\mathrm{D}$ values correspond to the reciprocal of the slope of those lines. The effect of pressure on the $\mathrm{D}$ value was also studied: the pressure (MPa) necessary to reduce the $\mathrm{D}$ value by 1 logarithmic cycle ( $\mathbf{Z}$ value) was calculated by regression analysis of the line obtained by plotting the logarithm of $\mathrm{D}$ values against the corresponding pressures. $\mathrm{Z}$ value corresponds to the reciprocal of the slope of that line.

\section{Kinetic Analysis and Reaction Order}

The denaturation process of a protein can be described by the general equation

$$
-\mathrm{dc} / \mathrm{dt}=\mathrm{kc}^{\mathrm{n}}
$$

where $-\mathrm{dc} / \mathrm{dt}$ represents the rate of protein denaturation, $\mathrm{k}$ is the rate constant, $\mathrm{c}$ is the protein concentration at each pressure, and $\mathrm{n}$ is the reaction order.

$$
\text { For } \mathrm{n}=1,-\mathrm{dc} / \mathrm{dt}=\mathrm{kc},-\mathrm{dc} / \mathrm{c}=\mathrm{kdt},
$$

and integrating,

$$
\ln \left(\mathrm{c}_{0} / \mathrm{c}_{\mathrm{t}}\right)=\mathrm{kt}
$$

is obtained, where $c_{0}$ is the initial protein concentration (for time 0 ) and $c_{t}$ is the concentration of undenatured protein at each holding time. When the denaturation process follows first-order kinetics, the graphical representation of Eq. [2] gives a straight line, and the value $\mathrm{b}$ of the ordinate intercept $(t=0)$ is close to zero. By regression analysis, the value of the constant $\mathrm{k}$ is obtained from the slope of the lines.

For $\mathrm{n} \neq 1$, when the general Eq. [1] is integrated,

$$
\left(\mathrm{c}_{\mathrm{t}} / \mathrm{c}_{0}\right)^{1-\mathrm{n}}=1+(\mathrm{n}-1) \mathrm{k}\left(\mathrm{c}_{0}\right)^{\mathrm{n}-1} \mathrm{t}
$$

is obtained. For non-first-order reactions, the representation of the results according to Eq. [3] yields straight lines, and from its slope the rate constant $\mathrm{k}$ is obtained.

The ordinate intercept (time $t=0$ ) for a non-firstorder reaction should be $b=1$ if the process follows the estimated reaction order.

\section{Calculation of Activation Volumes and Frequency Factors}

When the natural logarithm of the rate constants (ln $\mathrm{k}$ ) is plotted against the pressure, the values of the activation volumes and frequency factors can be determined using Eq. [4].

$$
\ln \mathrm{k}=\ln \mathrm{k}_{0}-\mathrm{pV}_{\mathrm{a}} / \mathrm{R} \mathrm{T},
$$

where $\mathrm{k}$ is the rate constant, $\mathrm{k}_{0}$ the frequency factor, $\mathrm{R}$ the universal gas constant, $\mathrm{T}$ the absolute temperature, $\mathrm{p}$ the pressure, and $\mathrm{V}_{\mathrm{a}}$ the activation volume.

\section{RESULTS AND DISCUSSION}

The effect of high-pressure treatment on denaturation of lactoferrin and lactoperoxidase in 3 different media, skim milk, whey, and phosphate buffer, was studied in this work. The degree of denaturation of lactoferrin subjected to pressure treatment was estimated by measuring the loss of reactivity with its specific antibodies using a sandwich ELISA. Conventional immunoassays rely on labeling the interaction of a protein and antibodies and, in general, are particularly useful for detecting conformational changes in proteins with concomitant lost of epitopes as a result of denaturation (Tremblay et al., 2003). These techniques have been widely used to study the effect of heat treatment on denaturation of whey proteins (Sánchez et al., 1992; Mainer et al., 1997; Wehbi et al., 2005). Calibration curves were obtained using the relationship between the values of the absorbance and the concentration of lactoferrin standards in PBS; the relationship was linear within the range from $10 \mathrm{ng} / \mathrm{mL}$ to $1 \mu \mathrm{g} / \mathrm{mL}\left(\mathrm{r}^{2}>0.97\right)$. The concentration of lactoferrin in the samples was determined by interpolating the corresponding absorbance in the standard curve obtained for each plate, which was adjusted to a second-order polynomial equation. Denaturation of lactoperoxidase was evaluated by determining the residual enzymatic activity. This activity was measured by a spectrophotometric method using ABTS as the substrate.

Previously, preliminary experiments were carried out to determine an appropriate range of pressures and times of treatment. We observed that lactoferrin in phosphate buffer and milk denatured slowly at 400 MPa. In contrast, denaturation of lactoferrin in whey was very fast at pressures above $700 \mathrm{MPa}$. Thus, a range from 450 to $700 \mathrm{MPa}$ was chosen. Furthermore, with the current commercial trend toward using higher pressures for shorter times, information is needed on the effect of higher pressures on whey and other food proteins (Walker et al., 2004).

Results obtained in the pressure treatment of lactoperoxidase from 450 to $700 \mathrm{MPa}$ indicated that the enzyme is highly resistant to pressure as it was not affected by any pressure treatment applied to milk, whey, or protein solutions, even after a treatment at $700 \mathrm{MPa}$ for $15 \mathrm{~min}$. Our results agree with those previously reported, which indicated that lactoperoxidase shows extreme resistance to high-pressure treatment. Ludikhuyze et al. (2001) observed that no substantial inactivation, or only minor inactivation, occurred after 
treatment of lactoperoxidase in milk and diluted whey, respectively, at $700 \mathrm{MPa}$ for $140 \mathrm{~min}$ at temperatures between $20^{\circ} \mathrm{C}$ and $65^{\circ} \mathrm{C}$. In fact, a very pronounced antagonistic effect between high temperature and pressure was observed by those authors; that is, at $73^{\circ} \mathrm{C}$, a temperature where thermal inactivation of lactoperoxidase at atmospheric pressure occurs rapidly, application of pressure up to $700 \mathrm{MPa}$ completely inhibits enzyme inactivation. The fact that pressure greatly slows the rate of inactivation during the early stage of thermal treatment indicates that a considerable increase in volume of the molecules occurs in going from the native to the activated state during pressure treatment (Johnson and Campbell, 1945). Likewise, Rademacher and Kessler (1997) reported that even after treatment of lactoperoxidase for $4 \mathrm{~h}$ at $800 \mathrm{MPa}$ and 40 to $60^{\circ} \mathrm{C}$, residual activities $>50 \%$ were measured. They attributed the high-pressure stability of lactoperoxidase to its monomeric structure, which is stabilized by 8 disulfide bonds. Seyderhelm et al. (1996) found that pressure treatment of raw bovine milk at $600 \mathrm{MPa}$ and 25 to $40^{\circ} \mathrm{C}$ for $30 \mathrm{~min}$ resulted in about $20 \%$ reduction of lactoperoxidase activity. Seyderhelm et al. (1996) also noted that about $70 \%$ of activity was lost when the enzyme was treated in Tris buffer, $\mathrm{pH} 7$, indicating that lactoperoxidase is more stable in milk than in buffer. However, we did not observe any reduction in lactoperoxidase activity in phosphate buffer after treatment at $600 \mathrm{MPa}$ at $20^{\circ} \mathrm{C}$ for $25 \mathrm{~min}$.

It has been also reported that the combination of high-pressure treatment and the lactoperoxidase system cause a strongly synergistic inactivation of a wide range of gram-negative and gram-positive bacteria. Therefore, lactoperoxidase may be an interesting additional technology to improve the safety of high-pressure food preservation (García-Graells et al., 2003).

Much has been published on the effect of highpressure treatment on the major bovine whey proteins $\beta$-LG and $\alpha$-LA (Huppertz et al., 2002, 2004; Anema et al., 2005; López-Fandiño, 2006). However, information is lacking about the effect of this technology on the minor whey proteins such as lactoferrin. In this study, we performed kinetic studies at a range of pressures and holding times to predict the level of denaturation of lactoferrin induced by pressure treatment.

Results obtained in this work indicated that the degree of lactoferrin denaturation increased with pressure and time of treatment (Figure 1). The graphs show the concentration of lactoferrin at each holding time expressed as a percentage of the initial protein concentration. The data in Figure 1 are the results of a single experiment, whereas mean values of duplicate data from 2 independent experiments were used to calculate all kinetic parameters. Data obtained in the pressure- induced denaturation of lactoferrin can be evaluated using processes similar to those used in studying thermal denaturation (Anema and McKenna, 1996; Claeys et al., 2003; Anema et al., 2005).

The $\mathrm{D}$ and $\mathrm{Z}$ values were calculated as described in Materials and Methods (Table 1 ). The CV of D values obtained from the different experiments for all pressures were $<11 \%$. At all pressures, D values were lower when lactoferrin was treated in whey than in milk, and were much lower in both than when lactoferrin was treated in phosphate buffer (Table 1). These results indicate that lactoferrin is denatured more slowly when it is treated in buffer than in milk, and more slowly in milk than in whey. Furthermore, D values changed as a function of pressure (Figure 2), giving $\mathrm{Z}$ values of 200.1, 283.5 , and $243.1 \mathrm{MPa}$ in milk, whey, and phosphate buffer, respectively (Table 1). These findings suggest a greater pressure dependence of the denaturation process for lactoferrin when it is treated in milk or buffer than in whey.

Results obtained in this work are in accordance with those reported for heat-treated lactoferrin, which was found to be more heat-sensitive when treated in milk than in phosphate buffer ( $\mathrm{pH}$ 7.4). This fact has been attributed to changes in the calcium phosphate bound to caseins, which changes to a more amorphous state with increasing temperature. Thus, interactions of lactoferrin with caseins would be enhanced and, consequently, lactoferrin heat sensitivity increased (Sánchez et al., 1992). The greater decrease of milk pH compared with that of phosphate buffer could also contribute to the low thermoresistance of lactoferrin when treated in milk. However, different behavior has been reported for other whey proteins subjected to high pressure, such as $\mathrm{IgG}$, which is more baroresistant in colostrum than in buffer (Indyk et al., 2008) or for $\beta-L G$ and $\alpha$-LA, which are more pressure-resistant in milk than in whey (Huppertz et al., 2004).

The values of immunoreactive lactoferrin after pressure treatment at different pressures and times were subjected to reaction kinetic analysis assuming a reaction order of $n=1.5$. The graphical representations of the ratio between concentration of denatured protein at each holding time and initial protein concentration plotted against time are shown in Figure 3. The slopes of those lines correspond to the rate constants (k) presented in Table 2. The straight lines obtained have coefficients of correlations $>0.87$ and intersect the ordinate close to 1 , as shown in the graphical representations and in Table 2. These results indicate that the value $n=1.5$ is suitable, at the pressures studied, to mathematically describe the process of lactoferrin denaturation. Other orders of reactions $(\mathrm{n}=1$ and $\mathrm{n}=$ 2 ) were tried and did not result in a better fit. 

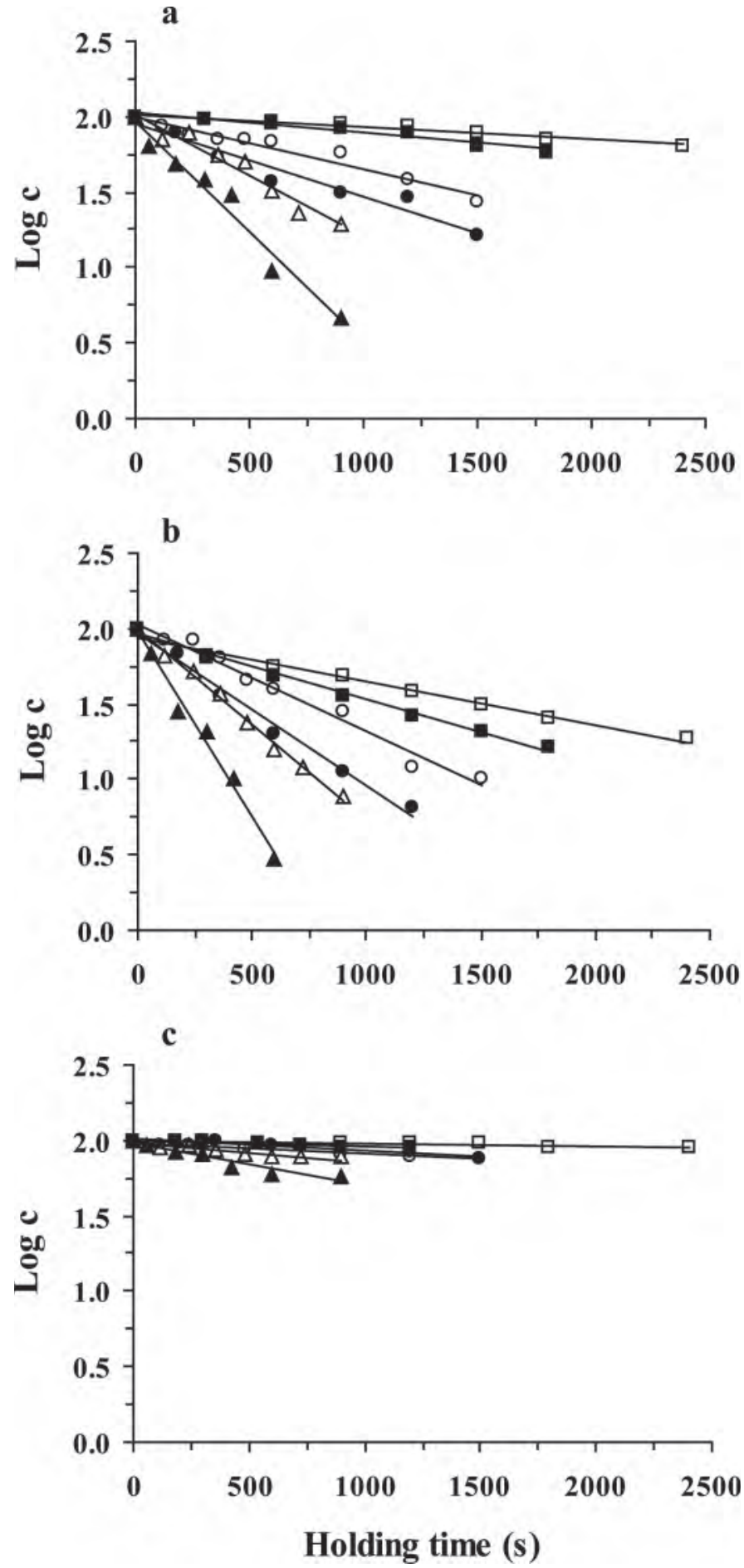

Figure 1. Effect of pressure treatment on the denaturation of lactoferrin in (a) skim milk, (b) whey, and (c) buffer at different pressures $(\square=450, \boldsymbol{\square}=500, \bigcirc=550, \boldsymbol{\bullet}=600, \Delta=650, \boldsymbol{\Delta}=700 \mathrm{MPa}) ; \mathrm{c}$ is the concentration of immunoreactive protein at each holding time expressed as percentage of the initial concentration.
Table 1. Values of $\mathrm{D}$ and $\mathrm{Z}^{1}$ for lactoferrin treated in skim milk, whey, and buffer at different pressures

\begin{tabular}{lrcc}
\hline Item & Milk & Whey & Buffer \\
\hline $\mathrm{D}_{450}(\mathrm{~s})$ & 12,092 & 3,463 & 46,729 \\
$\mathrm{D}_{500}(\mathrm{~s})$ & 7,435 & 2,316 & 25,510 \\
$\mathrm{D}_{550}(\mathrm{~s})$ & 2,917 & 1,406 & 13,623 \\
$\mathrm{D}_{600}$ (s) & 2,068 & 992 & 12,048 \\
$\mathrm{D}_{650}$ (s) & 1,220 & 798 & 7,710 \\
$\mathrm{D}_{700}$ (s) & 682 & 410 & 3,566 \\
$\mathrm{Z}$ (MPa) & 200.1 & 283.5 & 243.1 \\
\hline
\end{tabular}

${ }^{1} \mathrm{D}$ value $=$ time $(\mathrm{s})$ required for $90 \%$ protein denaturation at constant pressure (subscript shows pressure in $\mathrm{MPa}) ; \mathrm{Z}$ value $=$ pressure $(\mathrm{MPa})$ necessary to reduce $\mathrm{D}$ value by 1 logarithmic cycle.

The reaction order observed for the thermal denaturation of lactoferrin in skim milk and phosphate buffer has been reported to be $\mathrm{n}=1$ (Sánchez et al., 1992). To explain differences in the order of reaction of whey proteins subjected to thermal treatment, Dannenberg and Kessler (1988) postulated intermediate and consecutive reactions that would appear as a reaction of higher order. The same could be assumed for pressureinduced denaturation because the unfolding of proteins occurs under high-pressure conditions and is followed by the formation of aggregates (Hinrichs et al., 1996; Anema et al., 2005). Thus, the presence of disulfidebonded aggregates consisting of lactoferrin and other whey proteins has been observed in whey protein concentrated solutions subjected to high-pressure treatment (Patel et al., 2004). Differences in the reaction order of induced-denaturation of lactoferrin between thermal and pressure treatments suggests differences in the predominance of individual steps in the overall denaturation mechanism, as has been reported for other

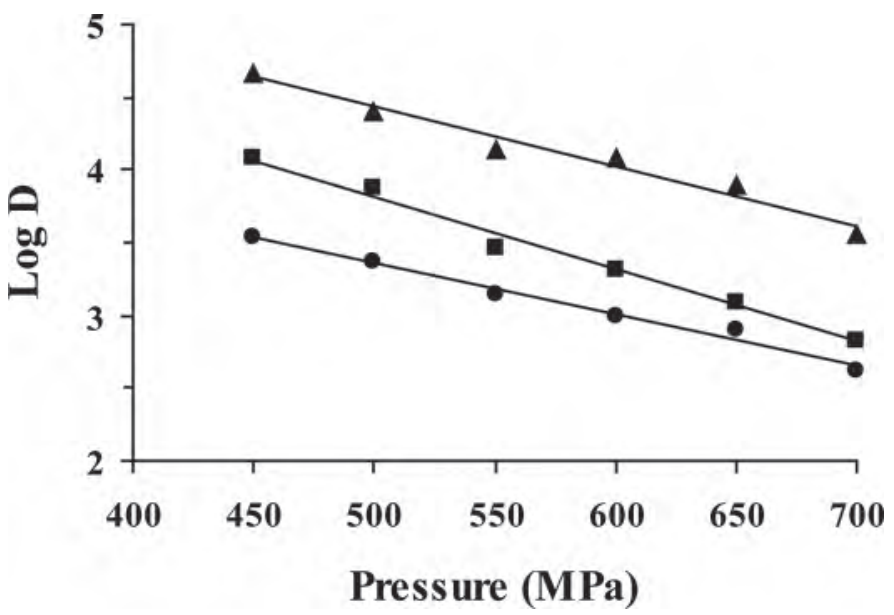

Figure 2. Effect of pressure on D values for the loss of immunoreactivity of lactoferrin in skim milk $(\boldsymbol{\square})$, whey $(\mathbf{\bullet})$, and buffer $(\mathbf{\Lambda})$. $\mathrm{D}$ value $=$ time $(\mathrm{s})$ required for $90 \%$ protein denaturation at constant pressure. 

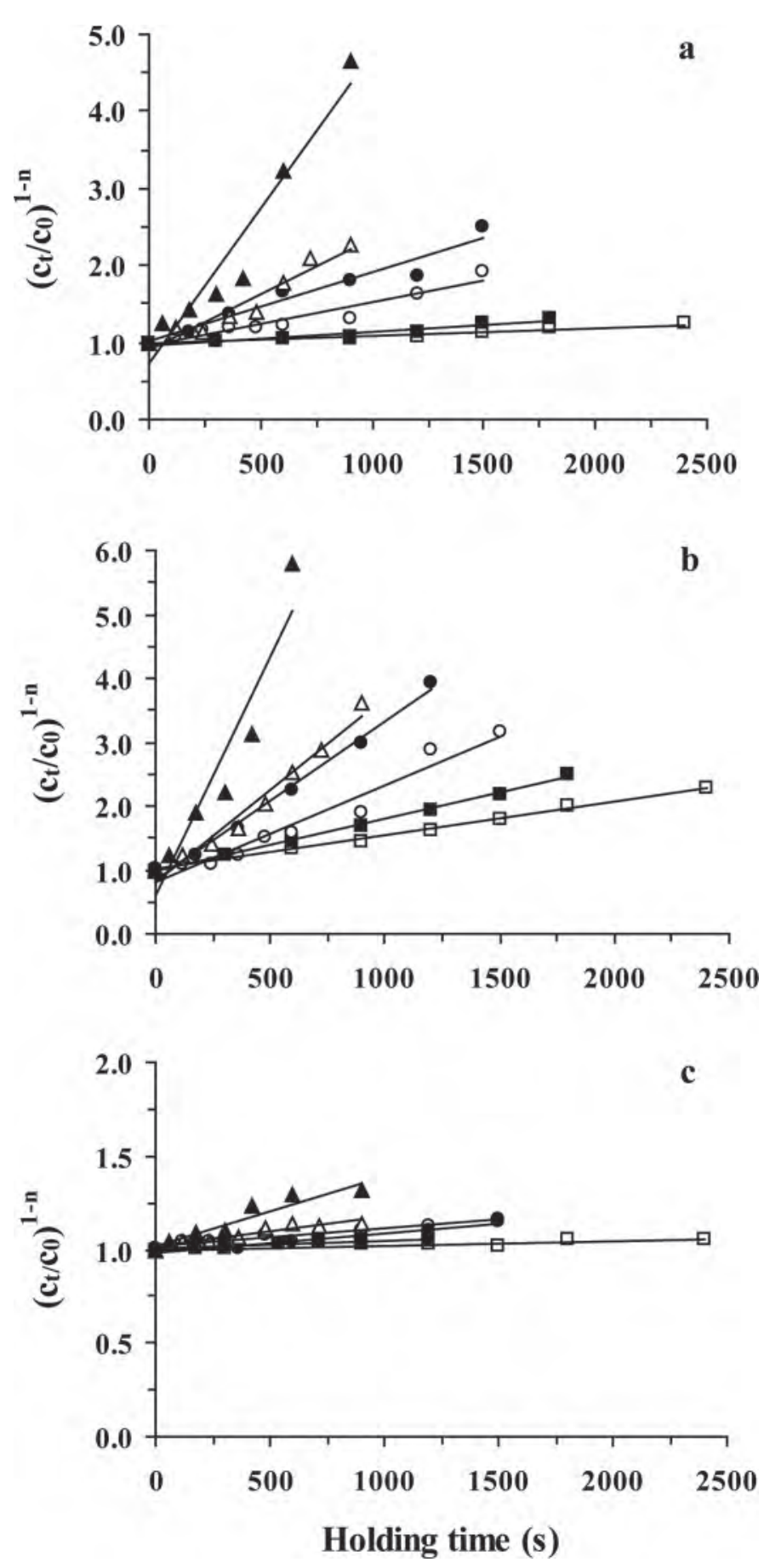

Figure 3. Denaturation of lactoferrin in (a) skim milk, (b) whey, and (c) buffer assuming a reaction order of $\mathrm{n}=1.5(\square=450, \mathbf{\square}=500$, $\mathrm{O}=550, \boldsymbol{\bullet}=600, \Delta=650, \boldsymbol{\Delta}=700 \mathrm{MPa}) ; c_{\mathrm{t}}$ is the immunoreactive protein concentration at each holding time, and $\mathrm{c}_{0}$ is the initial protein concentration.

whey proteins (Anema and McKenna, 1996; Anema et al., 2005).

As the denaturation reactions were performed at a range of pressures, the activation volumes $\left(\mathbf{V}_{\mathbf{a}}\right)$ and fre-

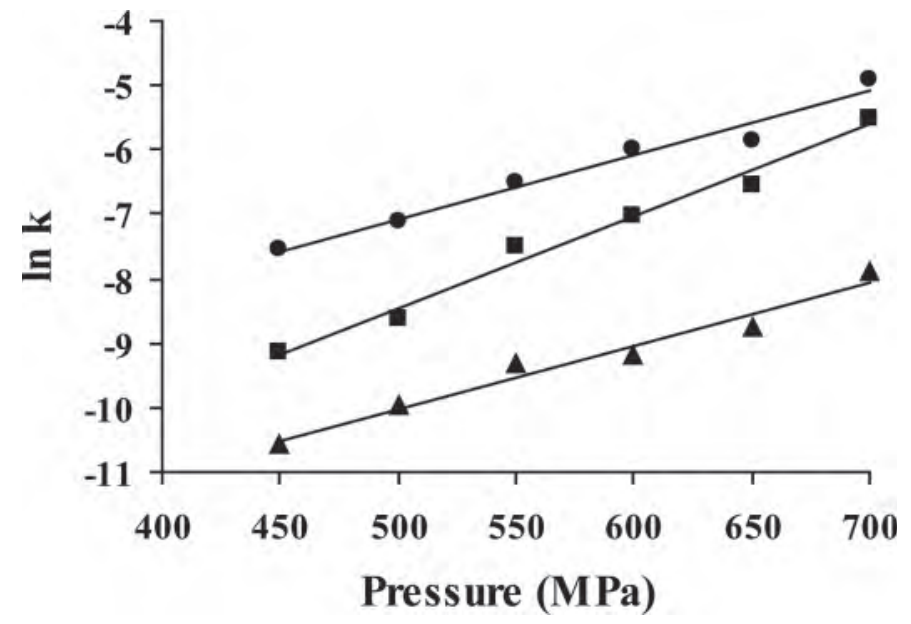

Figure 4. Relationship between $\ln \mathrm{k}$ (where $\mathrm{k}$ is the rate constant) and pressure for the denaturation of lactoferrin in skim milk (ם), whey $(\bullet)$, and buffer $(\mathbf{\Lambda})$.

quency factors ( $\mathbf{l n} \mathbf{K}_{\mathbf{0}}$ ) of lactoferrin for each treatment medium could be determined using Eq. [4]. The natural logarithms of the rate constants (ln k), obtained from the slopes of the straight lines shown in Figure 3, were plotted against pressure (Figure 4). The relationship between $\mathrm{ln} \mathrm{k}$ and pressure was linear in the overall pressure range for lactoferrin in the 3 media. The values of $\mathrm{V}_{\mathrm{a}}(-34.77,-24.35$, and $-24.09 \mathrm{~mL} / \mathrm{mol})$ and $\ln \mathrm{K}_{0}$ $(-15.60,-12.06$, and -14.97$)$ obtained for lactoferrin treated in milk, whey, or buffer, respectively, are in the range reported for the pressure-induced unfolding of other whey proteins (Hinrichs et al., 1996; Anema et al., 2005). In all cases, negative $\mathrm{V}_{\mathrm{a}}$ were obtained, which indicates that denaturation of lactoferrin follows Le Chatelier-Brown's principle, which predicts that under pressure, reactions of volume decrease are favored (Hinrichs et al., 1996; Royer, 2002). Negative $V_{\text {a values }}$ also indicate that the rate of denaturation of lactoferrin increases with pressure, as was observed in the current study.

To achieve a shelf life of milk of $10 \mathrm{~d}$ at a storage temperature of $10^{\circ} \mathrm{C}$, a pressure treatment of $400 \mathrm{MPa}$ for $15 \mathrm{~min}$ or $600 \mathrm{MPa}$ for $3 \mathrm{~min}$ at $20^{\circ} \mathrm{C}$ is necessary (Rademacher and Kessler, 1997). A similar treatment performed at $600 \mathrm{MPa}$ at $20^{\circ} \mathrm{C}$ would decrease immunoreactive lactoferrin to about 75,65 , and $98 \%$ in milk, whey, and buffer, respectively, compared with the corresponding untreated samples.

Kinetic parameters obtained in this work allow prediction of the pressure-induced denaturation of lactoferrin based on pressure and holding time. These parameters are greatly influenced by the composition of the medium. These aspects should be considered in the design of pressure treatments of lactoferrin to preserve 
Table 2. Results of the application of kinetic parameters ${ }^{1}$ to the denaturation of lactoferrin in skim milk, whey, and buffer, assuming a reaction order of $\mathrm{n}=1.5$, at different pressures

\begin{tabular}{|c|c|c|c|c|c|c|c|c|c|}
\hline \multirow{2}{*}{$\begin{array}{l}\text { Pressure } \\
(\mathrm{MPa})\end{array}$} & \multicolumn{3}{|c|}{ Milk } & \multicolumn{3}{|c|}{ Whey } & \multicolumn{3}{|c|}{ Buffer } \\
\hline & $\mathrm{k}$ & $\mathrm{b}$ & $r^{2}$ & $\mathrm{k}$ & $\mathrm{b}$ & $\mathrm{r}^{2}$ & $\mathrm{k}$ & $\mathrm{b}$ & $\mathrm{r}^{2}$ \\
\hline 450 & 1.06 & 0.979 & 0.943 & 5.26 & 1.017 & 0.992 & 0.25 & 0.998 & 0.877 \\
\hline 500 & 1.77 & 0.963 & 0.921 & 8.17 & 0.972 & 0.997 & 0.46 & 1.002 & 0.950 \\
\hline 550 & 5.54 & 0.967 & 0.921 & 15.26 & 0.810 & 0.954 & 0.91 & 1.020 & 0.951 \\
\hline 600 & 8.97 & 1.007 & 0.945 & 24.79 & 0.838 & 0.990 & 1.02 & 0.984 & 0.940 \\
\hline 650 & 14.59 & 0.901 & 0.935 & 28.94 & 0.812 & 0.972 & 1.61 & 1.016 & 0.896 \\
\hline 700 & 40.14 & 0.805 & 0.934 & 73.87 & 0.821 & 0.906 & 3.75 & 1.021 & 0.910 \\
\hline
\end{tabular}

${ }^{1}$ Parameters shown are rate constant $\left(\mathrm{k}, \mathrm{s}^{-1} \times 10^{4}\right)$, ordinate intercept $(\mathrm{b})$, and square correlation $\left(\mathrm{r}^{2}\right)$.

its integrity, and thus its biological function, when lactoferrin is added to special food or pharmaceutical products.

\section{ACKNOWLEDGMENTS}

This work was supported in part by grants 3rd Plan Tecnológico de Navarra from Navarra Government, P1078/09 from Aragón Government and European Social Fund. Chafiaa Mazri from the Institut National de la Recherche Agronomique d'Algerie is recipient of a fellowship from AECID. We thank Quesos Villa Corona (El Burgo de Ebro, Zaragoza, Spain) for providing fresh milk samples and to Fina Research (Seneffe, Belgium) for providing lactoferrin and lactoperoxidase.

\section{REFERENCES}

Anema, S. G., and A. B. McKenna. 1996. Reaction kinetics of thermal denaturation of whey proteins in heated reconstituted whole milk. J. Agric. Food Chem. 44:422-428.

Anema, S. G., R. Stockmann, and E. K. Lowe. 2005. Denaturation of $\beta$-lactoglobulin in pressure-treated skim milk. J. Agric. Food Chem. 53:7783-7791.

Catty, D., and C. Raykundalia. 1989. ELISA and related enzyme immunoassays. Pages 97-154 in Antibodies: A Practical Approach. Vol 2. D. Catty, ed. IRL Press, Oxford, UK.

Claeys, W. L., O. Indrawati, A. M. Van Loey, and M. E. Hendrickx. 2003. Review: Are intrinsic TTIs for thermally processed milk applicable for high-pressure process assessment? Innov. Food Sci. Emerg. Technol. 4:1-14.

Dannenberg, F., and H. G. Kessler. 1988. Thermodynamic approach to kinetics of $\beta$-lactoglobulin denaturation in heated skim milk and sweet whey. Milchwissenschaft 43:139-142.

Farnaud, S., and R. W. Evans. 2005. Lactoferrin: The conductor of the immunological system? Pages 47-76 in New Research on Immunology. B. A. Veskler, ed. Nova Science Publishers, New York, NY.

Franco, I., E. Castillo, M. D. Pérez, M. Calvo, and L. Sánchez. 2010. Effect of bovine lactoferrin addition to milk in yogurt manufacturing. J. Dairy Sci. 93:4480-4489.

García-Graells, C., I. Van Opstal, S. C. M. Vanmuysen, and C. W. Michiels. 2003. The lactoperoxidase system increases efficacy of high-pressure inactivation of foodborne bacteria. Int. J. Food Microbiol. 81:211-221.

Hinrichs, J., B. Rademacher, and H. G. Kessler. 1996. Reaction kinetics of pressure-induced denaturation of whey proteins. Milchwissenschaft 51:504-509.
Huppertz, T., P. F. Fox, and A. L. Kelly. 2004. High pressure-induced denaturation of $\alpha$-lactalbumin and $\beta$-lactoglobulin in bovine milk and whey: A possible mechanism. J. Dairy Res. 71:489-495.

Huppertz, T., A. L. Kelly, and P. F. Fox. 2002. Effects of high-pressure on constituents and properties of milk. Int. Dairy J. 12:561-572.

Indyk, H. E., J. W. Williams, and H. A. Patel. 2008. Analysis of denaturation of bovine IgG by heat and high pressure using an optical biosensor. Int. Dairy J. 18:359-366.

Johnson, F. H., and D. H. Campbell. 1945. Retardation of protein denaturation by high pressure. J. Cell. Comp. Physiol. 26:43-46.

López-Fandiño, R. 2006. Functional improvement of milk whey proteins induced by high hydrostatic pressure. Crit. Rev. Food Sci. Nutr. 46:351-363.

Ludikhuyze, L., W. Claeys, and M. Hendrickx. 2001. Effect of temperature and/or pressure on lactoperoxidase activity in bovine milk and acid whey. J. Dairy Res. 68:625-637.

Mainer, G., L. Sánchez, J. M. Ena, and M. Calvo. 1997. Kinetic and thermodynamic parameters for heat denaturation of bovine milk IgG, IgA and IgM. J. Food Sci. 62:1034-1038.

Marín, E., L. Sánchez, M. D. Pérez, P. Puyol, and M. Calvo. 2003. Effect of heat treatment on bovine lactoperoxidase activity in skim milk: kinetic and thermodynamic analysis. J. Food Sci. 68:89-93.

Masschalck, B., R. Van Houdt, and C. W. Michiels. 2001. High pressure increases bactericidal activity and spectrum of lactoferrin, lactoferricin and nisin. Int. J. Food Microbiol. 64:325-332.

Naidu, A. S. 2000. Lactoperoxidase. Pages 103-132 in Natural Food Antimicrobial Systems A. S. Naidu, ed. CRC Press, Boca Raton, FL

Nakada, M., S. Dosako, R. Hirano, M. Oooka, and I. Nakajima. 1996 Lactoperoxidase suppresses acid production in yoghurt during storage under refrigeration. Int. Dairy J. 6:33-42.

Patel, H. A., H. Singh, S. G. Anema, and L. K. Creamer. 2004. Effects of heat and high-hydrostatic pressure on the aggregarion of whey proteins concentrate solutions. Food New Zealand 4:29-35.

Pruitt, K. M., and D. N. Kamau. 1991. The lactoperoxidase system of bovine and human milk. Pages 133-174 in Oxidative Enzymes in Foods. D. S. Robinson, and N. A. M. Eskin ed. Elsevier Applied Science, London, UK.

Rademacher, B., and H. G. Kessler. 1997. High pressure inactivation of microorganisms and enzymes in milk and milk products. Pages 291-293 in High Pressure Research in the Biosciences and Biotechnology. K. Heremans, ed. Leuven University Press, Leuven, Belgium.

Rastogi, N. K., K. S. M. S. Raghavarao, V. M. Balasubramaniam, K. Niranjan, and D. Knorr. 2007. Opportunities and challenges in high pressure processing of foods. Crit. Rev. Food Sci. Nutr. 47:69-112.

Royer, C. A. 2002. Revisiting volume changes in pressure-induced protein unfolding. Biochim. Biophys. Acta 1595:201-209.

Sánchez, L., J. M. Peiro, H. Castillo, M. D. Pérez, J. M. Ena, and M. Calvo. 1992. Kinetic parameters for denaturation of bovine milk lactoferrin. J. Food Sci. 57:873-879. 
Seifu, E., E. M. Buysb, and E. F. Donkin. 2005. Significance of the lactoperoxidase system in the dairy industry and its potential applications: A review. Trends Food Sci. Technol. 16:137-154.

Severin, S., and X. Wenshui. 2005. Milk biologically active components as nutraceuticals: A review. Crit. Rev. Food Sci. Nutr. 45:645656.

Seyderhelm, I., S. Boguslawski, G. Michaelis, and D. Knorr. 1996. Pressure induced inactivation of selected food enzymes. J. Food Sci. 61:308-310.

Shah, N. 2001. Functional foods, probiotics and prebiotics. Food Technol. 55:46-53.

Singh, H. 2004. Heat stability of milk. Int. J. Dairy Technol. 57:111119

Tomita, M., H. Wakabayashi, K. Shin, K. Yamauchi, T. Yaeshima, and K. Iwatsuki. 2009. Twenty-five years of research on bovine lactoferrin applications. Biochimie 91:52-57.
Tremblay, L., M. F. Laporte, J. Leonil, D. Dupont, and P. Raquin. 2003. Quantitation of proteins in milk and milk products. Pages 49-138 in Advanced Dairy Chemistry. Vol. 1: Proteins. P. F. Fox, and L. H. McSweeney, ed. Kluwer Academic, New York, NY.

Wakabayashi, H., K. Yamauchi, and M. Takase. 2006. Lactoferrin research, technology and applications. Int. Dairy J. 16:1241-1251.

Walker, M. K., D. F. Farkas, S. R. Anderson, and L. Meunier-Goddik. 2004. Effects of high-pressure processing at low temperature on the molecular structure and surface properties of $\beta$-lactoglobulin. J. Agric. Food Chem. 52:8230-8235.

Ward, P. P., E. Paz, and O. M. Conneely. 2005. Multifunctional roles of lactoferrin: A critical overview. Cell. Mol. Life Sci. 62:2540-2548.

Wehbi, Z., M. D. Pérez, L. Sanchez, C. Pocovi, C. Barbana, and M. Calvo. 2005. Effect of heat treatment on denaturation of bovine alpha-lactalbumin: Determination of kinetic and thermodynamic parameters. J. Agric. Food Chem. 53:9730-9736. 